\title{
International Journal of Engineering Sciences \& Research Technology
}

(A Peer Reviewed Online Journal)

Impact Factor: 5.164
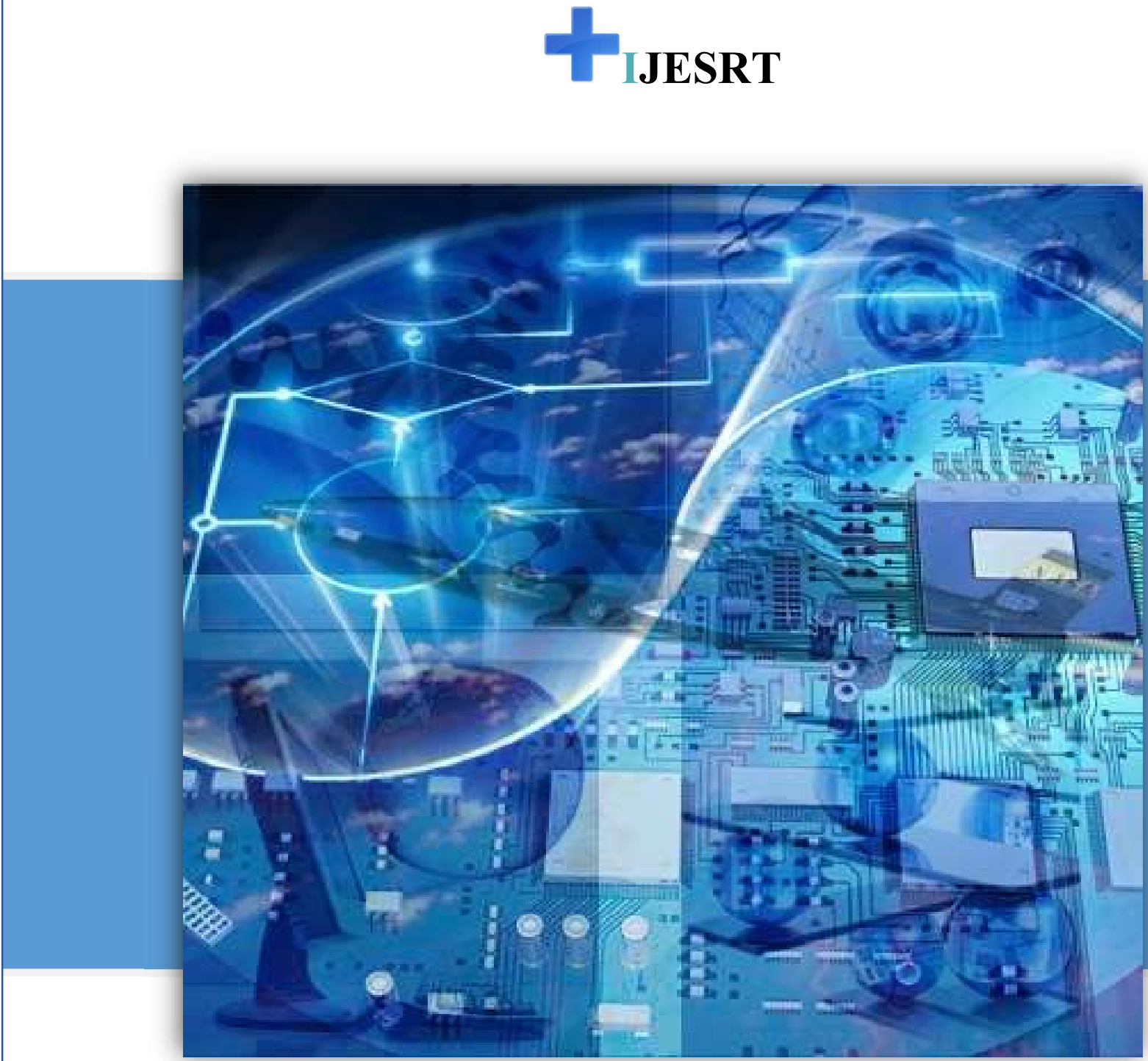

Chief Editor

Dr. J.B. Helonde
Executive Editor Mr. Somil Mayur Shah 


\title{
AIJESRT
}

\author{
INTERNATIONAL JOURNAL OF ENGINEERING SCIENCES \& RESEARCH \\ TECHNOLOGY \\ DOES INTRINSIC AND EXTRINSIC MOTIVATION AFFECT TO EMPLOYEE \\ PARTICIPATION IN TRAINING? \\ Irwan Yantu \\ Management Department, Faculty of Economics, Gorontalo State University
}

DOI: https://doi.org/10.29121/ijesrt.v10.i4.2021.3

\section{ABSTRACT}

In this study, the researcher intends to examine which factors most influence employee interest in participating in the training process provided, by taking the research focus on employees who work in banking companies. The location of banking is the object of research because banking institutions are also profit organizations that are quite intense in conducting regular training for their employees, both new employees and old employees who want to proceed to get a promotion. This study involved 72 respondents. The results of the study concluded that intrinsic and extrinsic motivation either partially or simultaneously had an effect on employee interest in attending training.

KEYWORD: Intrinsic Motivation; Extrinsic Motivation; Employee Participation.

\section{INTRODUCTION}

The productivity of a company is very dependent on the performance of its employees. As the main element in the managerial process, employees who are the company's resources become a lever in boosting the effectiveness of company performance (Paşaoğlu \& Tonus, 2014; McEvoy \& Buller, 2013). As stated by Hasibuan (2009) that productivity is referred to as the ratio between output and input, the increase is only possible by the efficiency of time-material-labor, work systems, and labor skills. Meanwhile, the skills of the workforce will be honed through the training process.

Training according to Simamora (2006) is a systematic process for changing employee behavior in a direction in order to improve organizational goals. In training, an environment is created where employees can acquire or learn specific attitudes, abilities, skills, knowledge and behaviors related to work. Training usually focuses on providing employees with specific skills or helping them correct weaknesses in their performance. To participate in the training process, a person will consider things that are generally said to affect their interests, such as health conditions, intellectual abilities, family conditions, and conditions where the training is held. These factors are later stated by Manihuruk (2012) as indicators that influence a person's interest in learning.

The intense training process carried out will improve employee skills, especially those directly related to the production process. So that employees need to be motivated to be interested in self-development through the training process provided. Attracting employees to take part in training can be done in various ways, including luring employees with the opportunity to get promotions and salary increases. Not only that, the desire to develop themselves through the training process can also be stimulated from within each employee. An interest in the work at hand, a willingness to develop, and the need for actualization can trigger employee enthusiasm and motivation to take part in the training process (Yantu, 2018).

This motivation by Hezberg in his two-factor theory quoted from (Tantawi et al., 2016) is referred to as intrinsic motivation and extrinsic motivation. Hezberg classifies individual motivation into two, namely motivation that comes from within the individual and motivation that comes from outside the person. Intrinsic motivation is a motivation whose trigger is a person himself, based on the fulfillment of spiritual needs which, when met, will create a sense of personal satisfaction. Both intrinsic and extrinsic motivation determine the form of performance achievement. The achievement of optimal performance is due to the motivation of employees (Muni et al., 2018). 
Regarding the work process, a person's intrinsic motivation is triggered by several indicators as described by (Kinman \& Kinman, 2001) in his research, namely: (1) Because of a sense of interest in work, (2) A person's desire to develop, (3) Pleasure with work involved, and (4) Feelings of enjoying work.

These aspects were later said by Kinman as factors that influence a person's motivation from within himself. The desire to develop and their interest in work will require someone to be interested in following the training process in order to improve their skills and capacity as an employee who is required to support the company's operational activities.

As for extrinsic motivation, Hezberg said that this motivation arises because of external stimuli and is usually physical. Extrinsic motivation usually arises because of something related to physical needs. Meeting daily needs forces a person to work in order to get something that can be used to make ends meet. Extrinsic motivation can arise with or without being supported by intrinsic motivation. Kinman \& Kinman (2001) stated that the aspects of extrinsic motivation consist of the following: (1) Pursuing status / strata, (2) There is competition between employees, (3) For self-evaluation, (4) Getting money and rewards, ( 5) To avoid punishment.

Seeing what Kinman said, it can be said that a person's interest or motivation in doing something is not all influenced by financial things. Some individuals are interested in participating in training because it has become a necessity for self-development, some are interested because they are pursuing status and all things inherent in it. This is also as concluded by Ning-Kuang et al., (2009) in their research entitled "Intrinsic and extrinsic factors impacting Casino hotel chef's job satisfaction" found that increased salary and compensation were not the only factors that influenced employee job satisfaction, in fact. It can be said that salaries and compensation do not have a meaningful contribution in creating job satisfaction, but there are other factors that come from within the employee which, if fulfilled, will provide individual satisfaction for the employee.

Another opinion was expressed by Ilyina (2013) in her research entitled Strategy and mechanisms of motivation and compensation in the organizations of the oil and gas industry that basically motivation and incentives have a close relationship, because motivation and incentive strategies are processes where employees or organizational personnel will its ability is stimulated in certain ways and methods in order to increase organizational capacity. From the two results of this study, it can be concluded that intrinsic and extrinsic motivation are related to one another, the diversity of needs of individuals makes the process of giving motivation to be carried out differently. So that in stimulating the interest of employees to participate in the training process, managerial parties must balance intrinsic and extrinsic factors. Intrinsically, employees must be given suggestions in order to generate a sense of interest and desire to develop. Meanwhile, from the extrinsic side, employees will be given rewards in both financial and non-financial forms if they want to participate in the training process (Kuvaas et al., 2017).

In this study, the researcher intends to examine which factors most influence employee interest in participating in the training process provided, by taking the research focus on employees who work in banking companies. Banking was chosen because it is one of the institutions that is quite intense in conducting regular training for its employees, both new employees and old employees who want to proceed to get a promotion.

\section{METHOD}

Broadly speaking, the research flow and the relationship between the variables studied can be described as shown in the following figure: 


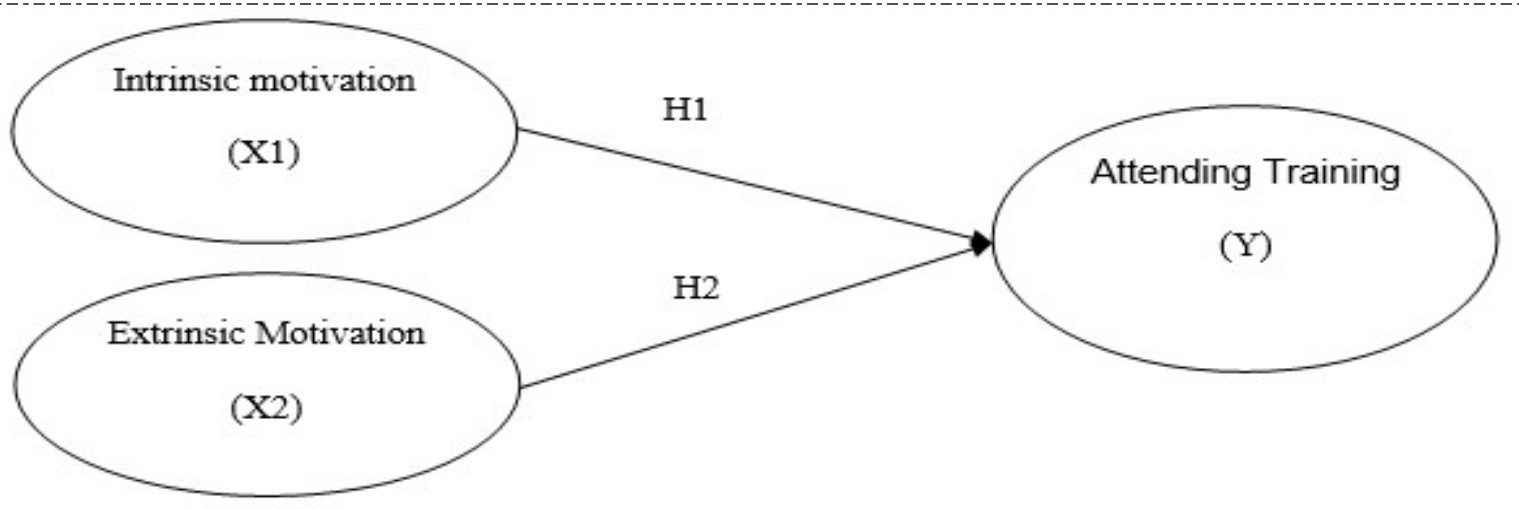

Figure 1. Research Design

The research was conducted using quantitative methods in which the researcher aims to explain the causal relationship between variables $\mathrm{X}$ and $\mathrm{Y}$ by involving 72 respondents who are permanent employees. Quantitative method is also a method used to examine a specific population or sample by using research instruments as a data collection tool, which aims to test predetermined hypotheses. (Sugiyono, 2015).

\section{RESULT}

\subsection{Normality Test}

The normality test is carried out in order to see whether the data is normally distributed or not. The basis for decision making is to look at the Kolmogrov Smirnov value if the significance value is $>0.05$ then the data is said to be normally distributed, otherwise if $<0.0$ then the data is not normally distributed. The results of the normality test showed that the data were normally distributed because the Kolmogrov Smirnov value for each variable was $>$ 0.05 . The value of each variable is 0.177 for variable $\mathrm{X} 1,0.064$ for variable $\mathrm{X} 2$, and 0.082 for variable $\mathrm{Y}$

Table 1. One-Sample Kolmogorov-Smirnov Test

\begin{tabular}{|c|c|c|c|c|}
\hline & $\mathrm{X} 1$ & $\mathrm{X} 2$ & $\mathrm{Y}$ \\
\hline & 72 & 72 & 72 \\
\hline \multicolumn{2}{|c|}{$\begin{array}{l}\mathbf{N} \\
\text { Normal Mean }\end{array}$} & 17.74 & 20.40 & 17.74 \\
\hline Parameters $^{\mathrm{a}, \mathrm{b}}$ & Std. Deviation & 1.661 & 2.620 & 1.601 \\
\hline Most Fytrem & Absolute & .130 & .175 & .149 \\
\hline $\begin{array}{l}\text { Most EXtrem } \\
\text { Differences }\end{array}$ & Positive & .130 & .131 & .101 \\
\hline Differences & Negative & -.124 & -.175 & -.149 \\
\hline Kolmogorov- & irnov Z & 1.101 & 1.485 & 1.263 \\
\hline Asymp. Sig. & ailed) & .177 & .064 & .082 \\
\hline
\end{tabular}

a. Test distribution is Normal.

b. Calculated from data.

\subsection{Multicolinearity Test}

The multicollinearity test results showed that there was no multicollinearity between variables. The conclusion is drawn by looking at the VIF value of each variable where the value for the variable $\mathrm{X} 1=1.276, \mathrm{X} 2=1.276$. As a requirement for the multicollinearity test, the variable is declared free from multicollinearity problems because the VIF value $<10$.

Dependent Variabel: Y

Table 2. Coefficients ${ }^{a}$

\begin{tabular}{|rr|r|r|}
\hline \multicolumn{2}{|c|}{ Model } & \multicolumn{2}{|c|}{ Collinearity Statistics } \\
\cline { 3 - 4 } \multicolumn{2}{|c|}{ (Constant) } & Tolerance & \multicolumn{1}{c|}{ VIF } \\
\hline & $\mathrm{X} 2$ & .784 & \\
\hline 1 & $\mathrm{X} 1$ & .784 & 1.276 \\
\hline & & & 1.276 \\
\hline
\end{tabular}

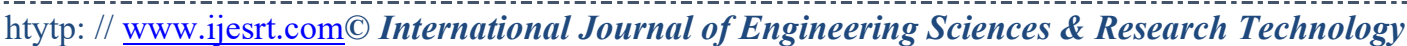




\subsection{Heteroscedasticity Test}

The Scatterplot diagram shows the results of the heteroscedasticity test. It can be seen in the appendix that the distribution pattern of the points is above and below the Y axis, so it can be concluded that this model does not have heteroscedasticity symptoms or there are no significant disturbances in this model.

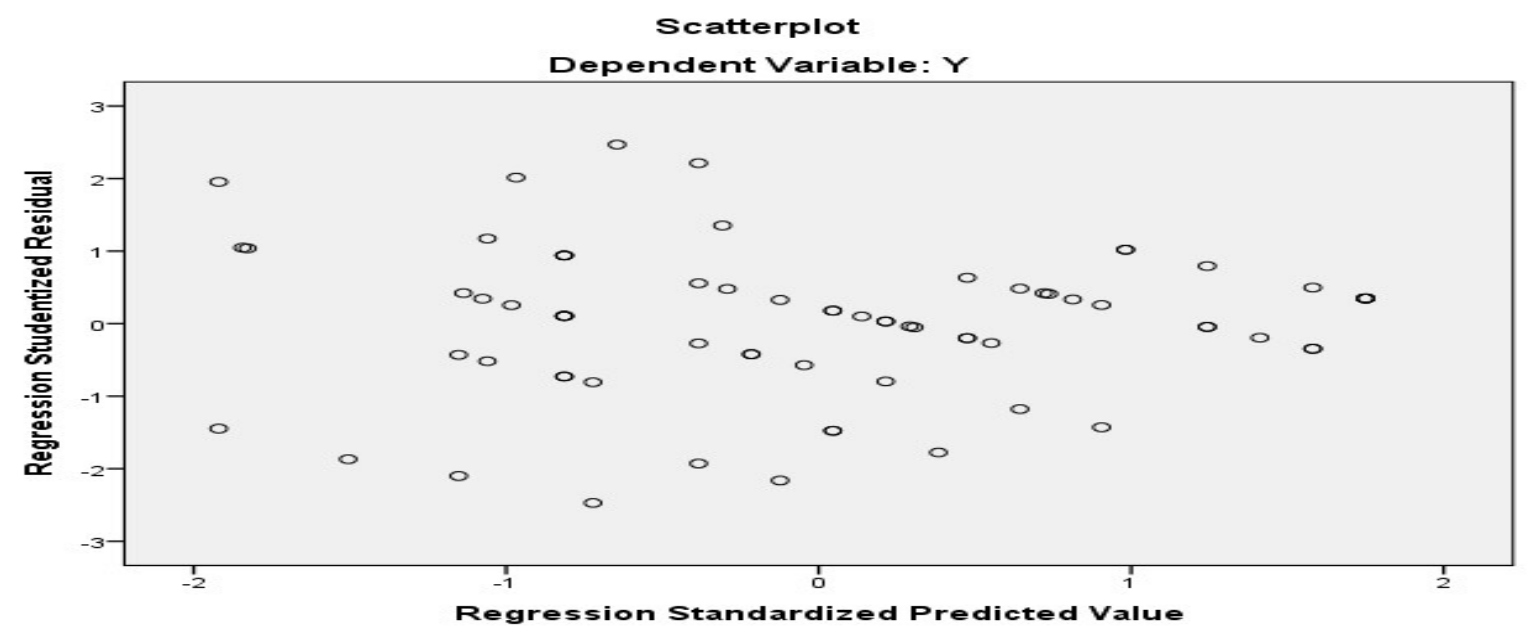

Figure 2. Scatterplot

\subsection{Multiple Regression Analysis}

Table 3. Hypothesis Testing Results

\begin{tabular}{|c|c|c|c|c|c|c|}
\hline Variable & $\begin{array}{c}\text { Coefficient } \\
\mathrm{B}\end{array}$ & T Count & T Table & R-Square & Significance & Inf. \\
\hline $\mathrm{X} 1 \longrightarrow \mathrm{Y}$ & 0.587 & 6.421 & 1.666 & 0.371 & 0.000 & Sig. \\
\hline $\mathrm{X} 2 \longrightarrow \mathrm{Y}$ & 0.313 & 4.995 & 1.666 & 0.263 & 0.000 & Sig. \\
\hline
\end{tabular}

Source: Processed Data (2017)

The results of hypothesis testing as presented in Table 3 show that there is a relationship between intrinsic motivation (X1) and employee interest in training (Y). The value of T count 6,421 which is greater than the value of T table, namely 1,666, concludes that there is indeed an effect of intrinsic motivation on employee interest in attending training. This effect is quite significant, seeing a significance value $<0.05$. The coefficient column $\mathrm{B}$ which shows the acquisition of a positive value indicates that the influence given is positive, in other words the better the process of providing intrinsic motivation, the more employee interest will be in participating in training. The R-square value shows that the amount of contribution made by intrinsic motivation in influencing employee interest is 0.371 or $37.1 \%$. The rest is influenced by other factors originating from outside.

As with intrinsic motivation, extrinsic motivation (X2) as listed in the table above also concludes that it has an influence on employee interest (Y). This is evidenced by the greater t value obtained, namely 4.995 compared to $t$ table which is only 1.666 . The effect given was very significant with a share of 0.263 or $26.3 \%$. These results indicate that the contribution of intrinsic motivation is still greater than extrinsic motivation. Therefore, it is necessary to focus on increasing the motivation that comes from within the employee. However, seeing the effect given by the two variables partially, it can be said that to attract employees to participate as participants in the training process requires support both from within and from outside the individual, because intrinsic motivation will be more effective if supported by a stimulus. of extrinsic motivation. 


\section{DISCUSSION}

\section{The Influence of Intrinsic Motivation on Employee Interest in Participating in Training}

Basically, an employee who has intrinsic motivation will tend to have the ambition to become an educated, intellectual, and professional individual. To achieve this, of course what is needed is self-development by learning and practicing. Without it, skills will not be honed and ambition will only be a dream. In the context of an organization / company, managerial parties always intensively organize training or education and training activities to mediate their employees who have the aim of increasing their own capacity. The motivation for employees to take part in this training will come from their needs. The need to become an educated, intelligent, and professional person will trigger their interest in following the training process.

The results of the study have shown that employees' interest in attending training is strongly influenced by intrinsic motivation. Ownership of intrinsic motivation in employees will affect their interest to push themselves better. Interest in participating in coaching will also emerge based on the awareness of each employee, having the essence of more than just joining in, wanting to be praised, or just pursuing promotions (Legault, 2020; Reiss, 2012). Without being lured by financial matters, with intrinsic motivation the employees will always be attracted by themselves to take part in training because there is a need and responsibility towards themselves.

\section{The Effect of Extrinsic Motivation on Employee Interest in Participating in Training}

Regarding extrinsic motivation, Sardiman (2005) in his book once said that this motivation functions when there is external stimulation. Most people with extrinsic motivation will be motivated to do something if there is feedback from the activity (Legault, 2020; Reiss, 2012). For example, employees who take training because they are oriented towards promotion or salary increases, not on the knowledge gained. Extrinsic motivation is very effective in stimulating employee interest in participating in training, this is because most of the fulfillment of human needs is always based on physical needs. If it is related to basic human needs as expressed by Maslow in Hasibuan (2009) physical needs (clothing, food, shelter) are the earliest needs to be met by humans. So that extrinsic motivation is always related to financial matters such as salary, promotion, and social status (Kuvaas et al., 2017).

Based on the results of the analysis, it was concluded that extrinsic motivation could influence employee interest in participating in the training process. In this connection, the leadership of the agency always held training every time the re-organization process was carried out. Rivai (2014) in his book also states that the process of recruitment, transfer, promotion is always accompanied by orientation activities. The orientation here is intended to train and introduce employees regarding the position they occupy and the main duties and functions attached to it. Therefore, in general, the manager always stimulates the interest of employees so that they want to take part in training because there will be re-organization. After the training is carried out, the manager will select employees who are entitled and deserving of a promotion or a salary increase.

\section{CONCLUSION}

Based on the explanation of the research results and the description of the above discussion, the following are the conclusions drawn by the researcher; (1) Intrinsic motivation has an effect on employee interest in attending

training. Ownership of intrinsic motivation in employees will affect their interest to push themselves better. Interest in participating in coaching will also emerge based on the awareness of each employee, having the essence of more than just joining in, wanting to be praised, or just pursuing promotions, (2) Extrinsic motivation has an effect on employee interest in attending training. Most people with extrinsic motivation will be motivated to do something if there is feedback from the activity. For example, employees who attend training because they are oriented towards promotion or salary increases, (3) Motivating employee interest must be done in a balanced manner. Intrinsic motivation of employees must be supported by providing motivation from outside that comes from organizational policies.

\section{RECOMMENDATION}

Referring to the conclusions above, the suggestions that can be given are: (1) Managerial parties are advised to always be able to advise their employees on the importance of employee self-development, so that employees are htytp: // www.ijesrt.com@ International Journal of Engineering Sciences \& Research Technology 
aware that training is carried out solely not for the benefit of the company but also for the benefit of employees, (2) Managerial parties are advised to aggressively motivate employees from outside. The desire that arises from within employees is not enough to motivate, it must be supported by the provision of rewards for employees who always motivate themselves.

\section{REFERENCES}

[1] A.M. Sardiman. 2005. Interaksi dan Motivasi Belajar Mengajar. Jakarta: Raja. Grafindo Persada

[2] Hasibuan, Malayu S.P. (2009). Manajemen: Dasar, Pengertian, dan Masalah. Edisi Revisi. Jakarta: Bumi Aksara.

[3] Ilyina, L. A. (2013). Strategy and Mechanisms of Motivation and Compensation in the Organizations of Oil and Gas Industry. Procedia Economics and Finance, 5(13), 346-354. https://doi.org/10.1016/s22125671(13)00041-5

[4] Kinman, G., \& Kinman, R. (2001). The role of motivation to learn in management education. Journal of Workplace Learning, 13(4), 132-144. https://doi.org/10.1108/13665620110391088

[5] Kuvaas, B., Buch, R., Weibel, A., Dysvik, A., \& Nerstad, C. G. L. (2017). Do intrinsic and extrinsic motivation relate differently to employee outcomes? Journal of Economic Psychology, 61, 244-258. https://doi.org/https://doi.org/10.1016/j.joep.2017.05.004

[6] Legault, L. (2020). Encyclopedia of Personality and Individual Differences. Encyclopedia of Personality and Individual Differences, October. https://doi.org/10.1007/978-3-319-28099-8

[7] McEvoy, G. M., \& Buller, P. F. (2013). Human resource management practices in mid-sized enterprises. American Journal of Business, 28(1), 86-105. https://doi.org/10.1108/19355181311314789

[8] Muni, A., Nurhayati, T., \& Widhiastuti, H. (2018). Analisa Pengaruh Pengembangan Karir Dan Motivasi Ekstrinsik, Motivasi Intrinsik Terhadap Kinerja Sdm Dengan Kepuasan Kerja Sebagai Variabel Intervening. Jurnal Riset Ekonomi Dan Bisnis, 11(3), 261. https://doi.org/10.26623/jreb.v11i3.1146

[9] Ning-Kuang, C., Dean, Y., \& Mary, D. (2009). Intrinsic and extrinsic factors impacting casino hotel chefs' job satisfaction. International Journal of Contemporary Hospitality Management, 21(3), 323-340. https://doi.org/10.1108/09596110910948323

[10] Paşaoğlu, D., \& Tonus, H. Z. (2014). Strategic Importance of Human Resource Practices on Job Satisfaction in Private Hospitals. Procedia - Social and Behavioral Sciences, 150(2545), 394-403. https://doi.org/10.1016/j.sbspro.2014.09.035

[11] Reiss, S. (2012). Intrinsic and Extrinsic Motivation. Teaching of Psychology, 39(2), 152-156. https://doi.org/10.1177/0098628312437704

[12] Tantawi, R., Armanu, A., \& Sudjatno, S. (2016). The Role of Job Motivation and Job Satisfaction in Mediating theEffect of Teacher's Certification on The Teacher's Performance in Gorontalo Elementary. Jurnal Aplikasi Manajemen, 14(4), 629-640. https://doi.org/10.18202/jam23026332.14.4.03

[13] Yantu, I. (2018). Organizational Climate for Work Motivation Stimulation in Regional Financial Agency. Jurnal Aplikasi Manajemen, 16(2), 330-335. https://doi.org/10.21776/ub.jam.2018.016.02.16. 